\title{
Estimation and testing of linkages between forest structure and rainfall interception characteristics of a Robinia pseudoacacia plantation on China's Loess Plateau
}

\author{
Changkun Ma $\mathrm{Ma}^{1,2} \cdot \mathrm{Yi} \mathrm{Luo}^{2,3} \cdot$ Mingan Shao ${ }^{2,3} \cdot$ \\ Xiaoxu Jia ${ }^{2,3}$
}

Received: 15 January 2020 / Accepted: 24 March 2020 / Published online: 6 June 2021

(C) The Author(s) 2021

\begin{abstract}
Understanding the interaction between canopy structure and the parameters of interception loss is essential in predicting the variations in partitioning rainfall and water resources as affected by changes in canopy structure and in implementing water-based management in semiarid forest plantations. In this study, seasonal variations in rainfall interception loss and canopy storage capacity as driven by canopy structure were predicted and the linkages were tested using seasonal filed measurements. The study was conducted in nine $50 \mathrm{~m} \times 50 \mathrm{~m}$ Robinia pseudoacacia plots in the semiarid region of China's Loess Plateau. Gross rainfall, throughfall and stemflow were measured in seasons with and without leaves in 2015 and 2016. Results show
\end{abstract}

Project funding: This study is supported by National Key

Research and Development Program (2016YFC0501603).

The online version is available at http://www.springerlink.com.

Corresponding editor: Zhu Hong.

Supplementary Information The online version contains supplementary material available at https://doi.org/10.1007/ s11676-021-01324-w.

Yi Luo

luoyi@igsnrr.ac.cn

$\triangle$ Mingan Shao

mashao@ms.iswc.ac.cn

1 State Key Laboratory of Eco-Hydraulics in Northwest Arid Region, Xian University of Technology, Xian, China

2 Key Laboratory of Ecosystem Network Observation and Modeling, Institute of Geographic Sciences and Natural Resources Research, Chinese Academy of Sciences, Beijing 100101, China

3 College of Resources and Environment, University of Chinese Academy of Sciences, Beijing 100190, China that measured average interception loss for the nine plots were $17.9 \%$ and $9.4 \%$ of gross rainfall during periods with leaves (the growing season) and without leaves, respectively. Average canopy storage capacity estimated using an indirect method was $1.3 \mathrm{~mm}$ in the growing season and $0.2 \mathrm{~mm}$ in the leafless season. Correlations of relative interception loss and canopy storage capacity to canopy variables were highest for leaf/wood area index (LAI/WAI) and canopy cover, followed by bark area, basal area, tree height and stand density. Combined canopy cover, leaf/wood area index and bark area multiple regression models of interception loss and canopy storage capacity were established for the growing season and in the leafless season in 2015. It explained $97 \%$ and $96 \%$ of the variations in relative interception loss during seasons with and without leaves, respectively. It also explained 98\% and $99 \%$ of the variations in canopy storage capacity during seasons with and without leaves, respectively. The empirical regression models were validated using field data collected in 2016. The models satisfactorily predicted relative interception loss and canopy storage capacity during seasons with and without leaves. This study provides greater understanding about the effects of changes in tree canopy structure (e.g., dieback or mortality) on hydrological processes.

Keywords Rainfall interception loss - Canopy storage · Canopy structure $\cdot$ Regression models $\cdot$ China's Loess Plateau

\section{Introduction}

Over the past several decades, large-scale afforestation efforts have been carried out in semiarid regions to convert farmlands, grasslands and shrublands into forest plantations because trees are vital for controlling desertification and soil 
erosion (Sexton et al. 2013; FAO 2015). In water-scarce areas where rain is the main source of water for vegetation growth, such changes in land use could have far-reaching effects on local water balances (Chang 2003). Thus, a thorough understanding of the interactions between afforestation and ecohydrological processes is needed for effective water resource management and land use planning in semiarid regions.

As a process, canopy interception loss $(I, \mathrm{~mm})$ is the fraction of rainwater retained in the canopy until it evaporates back into atmosphere, and it constitutes a net loss of $9 \%-60 \%$ of gross rainfall (Ma et al. 2019). The loss of this fraction to vegetation ecosystems not only modifies the energy and water balance of the surface atmosphere, but also exerts a negative effect on water use and the development of vegetation (Price and Carlyle-Moses 2003; Fathizadeh et al. 2017). $I$ is controlled by many factors, including canopy morphological traits (e.g., canopy storage capacity), rainfall characteristics (amount, duration and intensity), climatic conditions (e.g., wet canopy evaporation) and species composition (Crockford and Richardson 2000; Price and Carlyle-Moses 2003; Llorens and Domingo 2007). Among these factors, canopy storage capacity $(S)$, rainfall distribution and wet canopy evaporation rate are considered the key factors influencing $I$. To this end, several empirical and conceptual models have been developed based on these key factors to estimate the magnitude of $I$ (Rutter et al. 1975; Gash et al. 1995). In these models, the minimum rainwater needed to saturate the canopy is referred to as $S$ and it can be estimated either by using coupled gross rainfall and net rainfall (throughfall + stemflow) data (Klaassen et al. 1998; Wallace and McJannet 2008) or by scaling up through a water immersion method (Llorens and Gallart 2000). In rain events that are insufficient to saturate the canopy, almost all the rainwater retained in the canopy evaporates back into the atmosphere. When $S$ is exceeded however, some of the rainwater drips down from the canopy as throughfall and some is channeled down branches and stems as stemflow.

The amount of rainfall intercepted by the canopy $(S)$ depends on the vegetation type and canopy morphological characteristics (Galdos et al. 2012; Fathizadeh et al. 2017). For instance, in plants with distinct phenological characteristics such as deciduous trees, the magnitude of $I$ and $S$ change seasonally. This is because evaporation rate, and morphological and structural characteristics of the canopy change seasonally throughout the year (Pypker et al. 2005; Gerrits 2010). Domingo et al. (1998) pointed out that morphological and structural traits of forest canopies are the key factors affecting rainfall interception and hence the magnitude of $S$. Therefore, it is important that the linkages between $I, S$ and morphological characteristics of the canopy are understood in order to develop appropriate forest management practices and land use policies. However, studies relating $I$ and $S$ with morphological traits of canopies of forest plantations in semiarid areas are rare (Fathizadeh et al. 2017).

Canopy structural and morphological characteristics can be described using variables related to eco-physiological processes of vegetation. Such variables include canopy cover $(C)$, leaf area index (LAI), wood area index (WAI), basal area (BA) and bark surface area (BA_bark). These variables are descriptors of vegetation growth and are also used as input parameters in various eco-hydrological models (Gash et al. 1995; Hormann et al. 1996). Canopy cover, for example, defined as a percent of forest area occupied by vertical projection of the canopy, is a fundamental component of the landscape which influences rainfall interception, evapotranspiration, photosynthesis and other components of hydrological processes. Canopy cover is a key input of the revised Gash analytical model for the prediction of rainfall interception (Gash et al. 1995). Moreover, studies show that changes in $C$ have a strong effect on the flow of water in a watershed (Wang et al. 2008; Feng et al. 2016). Overall changes in $C$ exert significant effect on $I$, water yield and other hydrological processes. Thus, in a study of the impact of land cover changes on water yield, hydrological models should adequately incorporate parameterized sub-models which relate different variables of canopy morphology and physical processes of rainfall interception.

Aside from phenology, tree mortality results in distinct changes in morphological characteristics of forest canopy (Franklin et al. 1987). This usually involves complex interactions between endogenous factors such as stand characteristics and genetics, and exogenous factors such as stresses due to drought, climate, pests and diseases (Savage 1994; Allen and Breshears 1998; Guarin and Taylor 2005). Some of these factors were identified for the recent mortality of trees in the semiarid Loess Plateau region, where Robinia pseudoacacia was widely planted as a drought-tolerant, fastgrowing, nitrogen-fixing species, accounting for over $90 \%$ of species planted in the hilly-gully topography of the Plateau (Ma et al. 2017). The plantations suffered wild-spread dieback and mortality (Du et al. 2011; Jia et al. 2017). This reduced canopy cover leading to loss of canopy interception, and an increase of soil moisture and surface runoff (Anderegg et al. 2013; Fathizadeh et al. 2017). Thus, to assess the effect of plantation establishment and associated tree dieback/mortality on regional water balances, it is important to understand the interactions between canopy structure and canopy hydrological components $I$ and $S$. Since the calculations of $I$ and $S$ are expensive and time-consuming, the use of selected measurable morphological traits as predictors is an efficient alternative for application in forest management and policy making. The specific objectives of this study were to: (1) identify the key variables of canopy structure that best predict canopy hydrological components $I$ and $S$; and, (2) estimate and validate the relationship between the variables 
of canopy structure and $I$ and $S$ during the growing season and the period without leaves.

\section{Materials and methods}

\section{Study site}

The field experiment was conducted from 1st Jan. 2015 to 31 st Dec. 2016 in the Yeheshan watershed $\left(34^{\circ} 31.76^{\prime} \mathrm{N}\right.$, $107^{\circ} 54.67^{\prime}$ E, Fig. 1), located in the Yeheshan Provincial nature forest reserve in Fufeng County, Shaanxi Province. The reserve area is 10996 ha with an elevation range of 449-1662 $\mathrm{m}$ a.s.1.

The area has a monsoon semiarid continental climate characterized by hot, humid summers (June-August) and cold dry winters (December-February). According to the Fufeng Bureau of Meteorology (which lies $<10 \mathrm{~km}$ south of the watershed), long-term (1958-2016) mean annual air temperature is $12.7^{\circ} \mathrm{C}$, relative humidity $72 \%$, wind speed $1.5 \mathrm{~m} \mathrm{~s}^{-1}$ and precipitation $580 \mathrm{~mm}$. Precipitation mainly occurs during the growing season ( $\sim 81 \%$ of the annual total) and has a large inter-annual variation (coefficient of variation of 0.3 ).

The Yeheshan watershed has a hilly-gully topography typical of the Loess Plateau. The main soil type is silt loam with mean particle size distribution of $73.4 \%$ silt, $20.9 \%$ clay and $5.8 \%$ sand. The water table is over $50 \mathrm{~m}$ below the surface. Forest covers $\sim 90 \%$ of the watershed and is made up of a mosaic of pure plantation stands of different deciduous and coniferous species, dominated by Robinia pseudoacacia plantations.

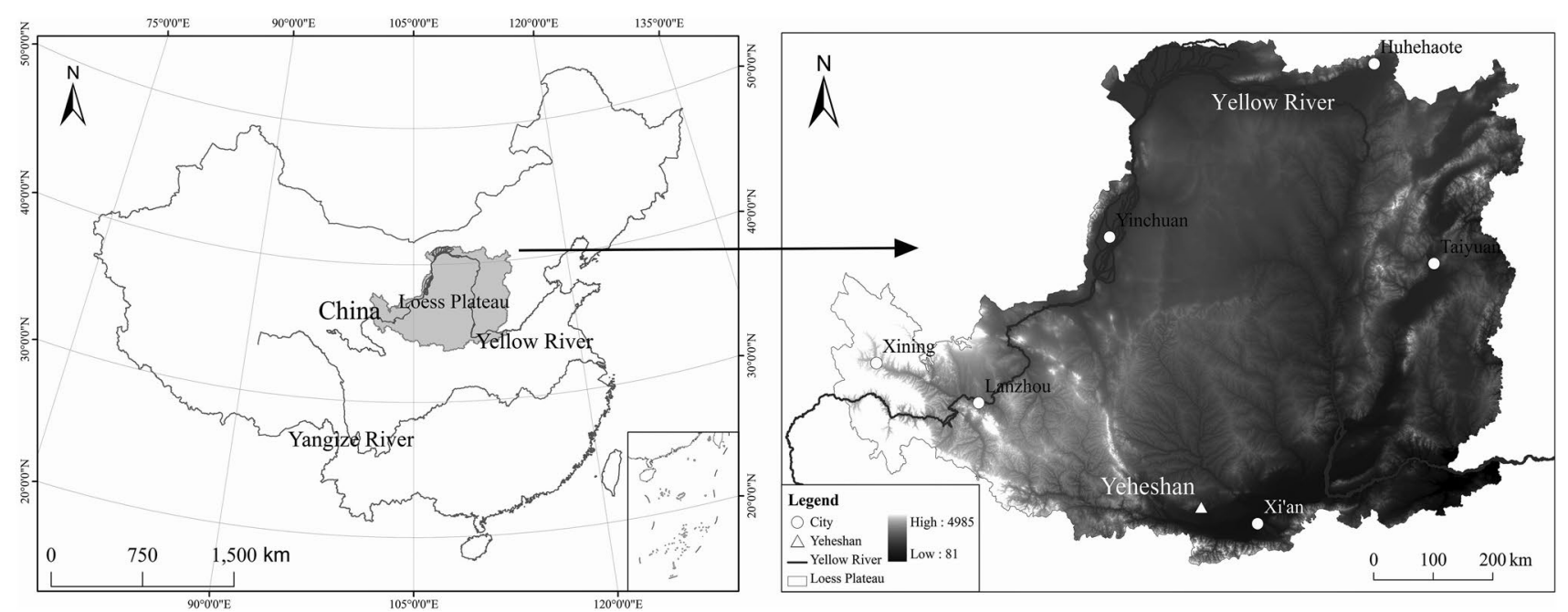

Fig. 1 Location of the study site

Table 1 Characteristics of the experimental plots

\begin{tabular}{lllllrlrrrrr}
\hline Plot & Latitude & Longitude & Slope & Asp. & Elev & Den & $D_{\mathrm{BH}}$ & Height & BA & $C$ & LAI \\
\hline & $34.55 \mathrm{~N}$ & $107.9223 \mathrm{E}$ & $7^{\circ}$ & $\mathrm{SW}$ & 920 & 1480 & 11.8 & 11.2 & 16.5 & 0.54 & 1.50 \\
2 & $34.5507 \mathrm{~N}$ & $107.9226 \mathrm{E}$ & $5^{\circ}$ & $\mathrm{SW}$ & 930 & 1600 & 11.7 & 11.1 & 17.5 & 0.53 & 1.48 \\
3 & $34.5501 \mathrm{~N}$ & $107.9239 \mathrm{E}$ & $5^{\circ}$ & $\mathrm{S}$ & 940 & 1720 & 11.7 & 10.7 & 17.8 & 0.56 & 1.54 \\
4 & $34.5492 \mathrm{~N}$ & $107.9233 \mathrm{E}$ & $4^{\circ}$ & $\mathrm{S}$ & 915 & 1520 & 11.2 & 11.2 & 14.3 & 0.54 & 1.45 \\
5 & $34.5718 \mathrm{~N}$ & $107.9269 \mathrm{E}$ & $7^{\circ}$ & $\mathrm{S}$ & 1040 & 1120 & 9.5 & 8.5 & 8.6 & 0.37 & 1.05 \\
6 & $34.5542 \mathrm{~N}$ & $107.9265 \mathrm{E}$ & $5^{\circ}$ & $\mathrm{S}$ & 1020 & 1240 & 9.7 & 8.3 & 10.7 & 0.35 & 1.01 \\
7 & $34.5625 \mathrm{~N}$ & $107.9113 \mathrm{E}$ & $9^{\circ}$ & $\mathrm{SE}$ & 1085 & 2000 & 10.8 & 9.7 & 17.9 & 0.49 & 1.42 \\
8 & $34.56 \mathrm{~N}$ & $107.92 \mathrm{E}$ & $9^{\circ}$ & $\mathrm{SE}$ & 1050 & 1800 & 11.0 & 10.3 & 17.8 & 0.48 & 1.38 \\
9 & $34.5584 \mathrm{~N}$ & $107.9195 \mathrm{E}$ & $7^{\circ}$ & $\mathrm{S}$ & 1035 & 2080 & 10.5 & 9.4 & 17.1 & 0.46 & 1.39 \\
Mean & - & - & - & - & 993 & 1618 & 10.9 & 10.0 & 15.4 & 0.48 & 1.35 \\
\hline
\end{tabular}

Asp. is aspect, Elev. is elevation (m.a.s.l.), Den. is tree density (tree $\mathrm{ha}^{-1}$ ), $D_{\mathrm{BH}}$ is diameter at breast height $(\mathrm{cm})$, Height is tree height $(\mathrm{m})$, BA is basal area $\left(\mathrm{m}^{2} \mathrm{ha}^{-1}\right), C$ is canopy cover, LAI is leaf area index $\left(\mathrm{m}^{2}\right.$ $\mathrm{m}^{-2}$ ), data are the mean of respective experimental plot during both leaf and leafless seasons in 2015 and 2016 
Nine $50 \mathrm{~m} \times 50 \mathrm{~m}$ plots in one Robinia plantation with different structural characteristics were selected and established at least $50 \mathrm{~m}$ from each other (Table 1). The plots were located in a relatively gentle slope with gradients of $4-9^{\circ}$. The Robinia plantation was established in 2002 on former farmlands and there were no systemic management practices because of prohibitions under protection forest laws. The understory is species of grasses, including Stipa bungeana Trinius, Artemisia sacrorum Ledeb. and Artemisia scoparia Waldst et Kit. Detailed description of the characteristics of forest structure in the experimental plots is summarized in Table 1.

\section{Gross rainfall, throughfall and stemflow}

From 1st Jan. 2015 to 31st Dec. 2016, measurements of gross rainfall, throughfall and stemflow were taken simultaneously for each forest plot. Gross rainfall was measured using both automatic and manual rain gauges. Three manual funnel rain gauges ( $30 \mathrm{~cm}$ diameter) were installed $<30 \mathrm{~m}$ from each plot in the open. Manual rain gauges were positioned $0.8 \mathrm{~m}$ above the forest floor to avoid splash and prevent damage from animals. The horizontal angle between the gauge and the surrounding tree rows was reduced to less than $45^{\circ}$ in order to reduce any disturbance from the surrounding environment on gauge measurement. Due to limited financial resources, only two T-200B type weighing bucket rain gauges (Geonor AS, Eiksmarka, Norway) were used in the study. The two automatic rain gauges were connected to a CR1000 data logger (Campbell Scientific Inc., Logan, UT, USA) and installed in an open location $<30 \mathrm{~m}$ next to plots 5 and 7 . The manual rain gauges were read immediately after each rainfall event. In the study area, a rainfall event is defined as a period with more than $0.2 \mathrm{~mm}$ of total rainfall occurring at least six hours apart (Ma et al. 2019). Field measurements with two leaf wetness sensors (237L, Campbell Scientific Inc., Logan, UT, USA) confirmed that this time interval was sufficient for the canopy to dry completely. During the experimentation period, there were good matches between manual and automatic rain gauges readings $(<5 \%$ of difference), with no systematic bias. Therefore, the average rain gauge was used in the analysis of rainfall partitioning.

Throughfall in each plot was measured using 30 manual rain gauges identical to those used for gross rainfall measurement. The throughfall rain gauges were installed randomly under and between trees in each plot, and covered by a nylon mesh to prevent leaves and other debris from entering the collectors and to reduce rainwater loss through splashing. To reduce spatial variability of throughfall measurements, half of the rain gauges were replaced randomly in new positions after every three rainfall events (Crockford and Richardson 2000). The stand level throughfall was determined as the average of the 30 rain gauges in each plot.
Stemflow was measured on 13 trees in each plot and was collected using spiral stemflow collars constructed from ordinary $20-\mathrm{cm}$ plastic garden hoses. The garden hose was attached at breast height in an upward spiral pattern using silicon sealant. In the case of trees with rough bark, the bark was shaved prior to installation of the stemflow collar. Stemflow down the trunks was diverted to a 50-L bucket placed at the base of the tree. Stemflow depth $\left(S_{\mathrm{f}}\right)$ was determined as:

$S_{f}=\frac{V_{\mathrm{SF}}}{\mathrm{CA}}$

where, $V_{S F}$ is stemflow volume and $C A$ is canopy area $\left(\mathrm{m}^{2}\right)$. Tree level stemflow depth was scaled up to the stand level following Fan et al. (2014) using Eq. (2):

$S_{f_{\text {_tand }}}=\sum_{i=1}^{n} \frac{S_{n} \cdot m}{A \cdot 10^{4}}$

where $S_{f_{-} \text {stand }}$ is the upscaled stemflow depth (mm) for a specified stand area of $\mathrm{A}\left(\mathrm{m}^{2}\right) ; n$ is the number of $D_{\mathrm{BH}}$ classes; and $S_{n}$ the average stemflow volume (ml) collected from $\mathrm{m}$ trees in the $D_{\mathrm{BH}}$ class.

Interception loss $(\mathrm{mm})$ was determined as the difference between gross rainfall amount and the sum of throughfall and stemflow.

\section{Canopy storage capacity (S)}

Canopy storage capacity $(S)$, is the maximum amount of rainwater a canopy can hold (Klaassen et al. 1998). $S$ can be estimated from direct and indirect methods (Pypker et al. 2005; Sadeghi et al. 2015). Due to the relatively low cost and lack of complex instrumentation, the regression-based indirect method proposed by Wallace and McJannet (2008) was used in this study to extrapolate the linear relationship between gross rainfall and the sum of throughfall and stemflow for a rainfall event large enough to saturate the canopy. $S$ was recorded as the negative intercept on the y-axis for the established relationship where gross rainfall minus the sum of throughfall and stemflow is equal to $S$.

\section{Canopy parameter measurement}

Leaf area index (LAI) and canopy cover $(C)$ are two physiological parameters widely used to quantify the forest canopy structure, and are also good indicators of tree growth and phenology (Fathizadeh et al. 2017; Tie et al. 2017). The crown and leaf surfaces are the main sites for rainwater retention and are reflected by LAI and $C$ in controlling canopy rainfall interception. To investigate the relationship between rainfall interception and canopy structure, LAI and $C$ were estimated using hemispherical photographs taken 
with a Nikon D100 digital camera fitted with a fish-eye adapter lens (Baret and Weiss 2004). LAI and $C$ were measured twice every month (on the first and on the last 10 days) in each plot. Twelve photographs were taken each time within each plot on cloudy days or at dusk or dawn under uniform sky conditions. To reduce the effect of the surrounding environment on LAI and $C$ estimates, the camera was oriented such that the edge of the photo was perpendicular to the tree row in each plot (Macfarlane et al. 2007). The photos were processed using CAN-EYE software (version

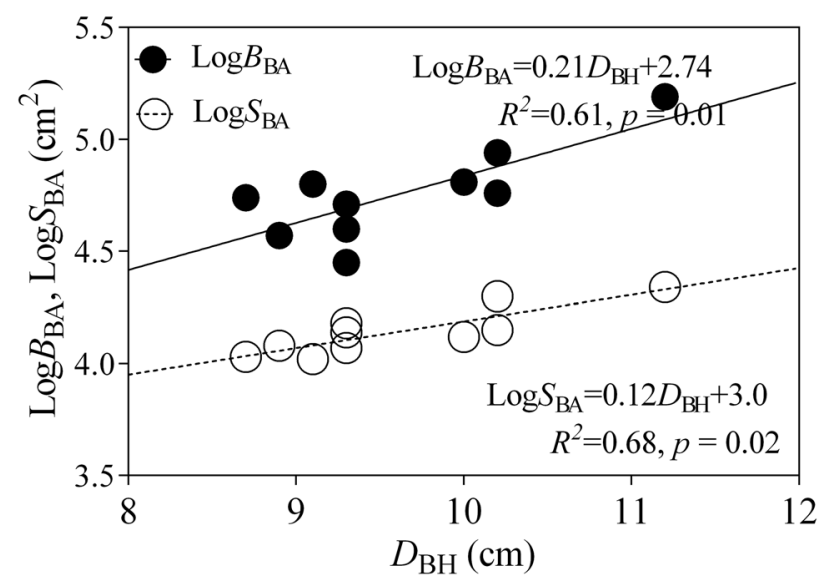

Fig. 2 Relationship between $D_{\mathrm{BH}}(\mathrm{cm})$ and bark surface area $\left(B_{\mathrm{BA}}\right.$, branch bark surface area; $S_{\mathrm{BA}}$, stem bark surface area, $\mathrm{cm}^{2}$ ) for a $R o b$ inia plantation; data were log transformed and significance of linear regression verified using $F$-test $(p<0.05)$
6.3) to obtain LAI (during the leaf season), WAI (during the leafless season) and $C$ for each forest site.

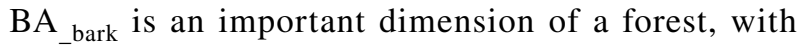
significant implications for respiration, energy exchange, and water and mineral budgets (Whittaker and Woodwell 1967). To estimate BA_bark of Robinia pseudoacacia in this study, allometric equations which relate $D_{\mathrm{BH}}$ to stem bark surface area $\left(S_{\mathrm{BA}}\right)$ and branch bark surface area $\left(B_{\mathrm{BA}}\right)$ were used, and the two formed the components of the BA_bark. The allometric equation was developed using an extentsive destructive sampling method. In October 2014, 10 Robinia trees were felled next to the experimental plots, and the bark surface area of trunks and branches measured according to Whittaker and Woodwell (1967). The logarithms of the variables were then regressed with the logarithms of $D_{\mathrm{BH}}$. A detailed description of the equations is shown in Fig. 2. Other forest morphological characteristics such as stand density (trees/ha), height (TH), basal area (BA) were also measured in each plot.

\section{Statistical analysis}

One-way ANOVA analysis $(p<0.05)$ was used to test statistical differences of the percentages of throughfall, stemflow and interception loss between leaf and leafless seasons. Additionally, multiple linear regression models were developed using field measurements in leaf and leafless seasons in 2015 to determine the relationship between relative canopy interception losses (ratio of interception
Fig. 3 Canopy storage capacity $(S)$ was estimated from the regression-based indirect method (Wallace and McJanner 2008), relative interception loss was calculated as the ratio between measured interception loss and gross rainfall (GR)

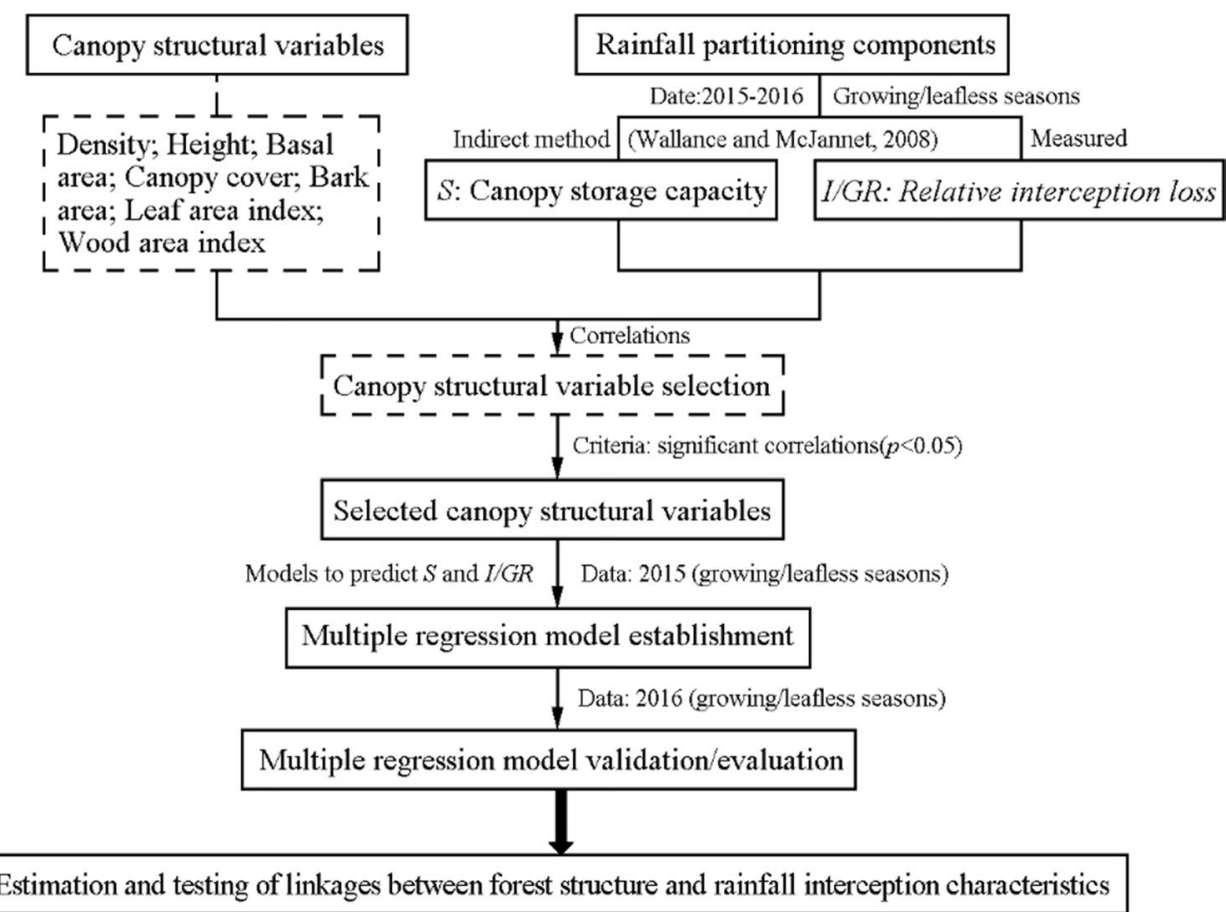


loss to gross rainfall), $S$ and canopy parameters of $C$, LAI, WAI and BA. Data obtained in the seasons with and without leaves in 2016 were used to validate the regression models. The differences in observed and predicted relative canopy interception loss and $S$ were evaluated using the coefficient of determination $\left(R^{2}\right)$ and root mean square error (RMSE). High values of $\mathrm{R}^{2}$ and low values of RMSE indicated high accuracy of the developed regression models in predicting relative interception loss (ratio of interception loss to total gross rainfall) and $S$. The descriptive regressions and statistics were performed using SPSS 25.0 statistical software (SPSS Inc., Chicago, IL, USA). The flowchart of this study is shown in Fig. 3.

\section{Results}

\section{Rainfall partitioning}

The measured rainfall and the partitioned components (i.e., throughfall, stemflow and interception loss) during the growing season and months without leaves in 2015 and 2016 are given in Table 2. A total of 163 rainfall events were identified during the two years in the season with leaves, the growing season (120 events) and the season without leaves (43 events), resulting in a cumulative rainfall of $1002.1 \mathrm{~mm}$ $\left(80.7 \%\right.$ of total gross rainfall $\left(P_{\mathrm{g}}\right)$ in the growing season and $240.1 \mathrm{~mm}\left(19.3 \%\right.$ of $\left.P_{\mathrm{g}}\right)$ in the leafless season These percentages were similar to the long-term (1958-2014) mean seasonal values of $80.5 \%$ in the growing season and $19.5 \%$ in the leafless season. The range of rainfall was $0.2-57.6 \mathrm{~mm}$ in the growing season, with an average of $8.4 \mathrm{~mm}$ and SD of $\pm 11.4 \mathrm{~mm}$. The corresponding amounts in the leafless season was $0.2-41.6 \mathrm{~mm}$, with an average (SD) of $5.6 \mathrm{~mm}$ $( \pm 6.7 \mathrm{~mm})$.

Overall, the average cumulative throughfall was $1020.5 \pm 297.9 \mathrm{~mm}$, accounting for $82.2 \%$ of $P_{\mathrm{g}}$. The average was $80.6 \%$ during the growing season, with a range of $77.6 \%-85.0 \%$. This increased to $88.7 \%$ in the leafless season, with a range of $86.9 \%-91.1 \%$ (Table 2). The average cumulative stemflow across the plots was $15.3 \mathrm{~mm}$ for the growing season and $4.6 \mathrm{~mm}$ for the leafless season, with the former accounting for $1.5 \%$ and the latter for $1.9 \%$ of the rainfall. In contrast to throughfall and stemflow percentages, average interception loss $\left(I: P_{\mathrm{g}}\right)$ was higher in the growing season $(17.9 \%)$ than for the months without leaves $(9.2 \%)$. However, the difference between the two seasons was not significant at $p=0.46$ (Table 2). Accordingly, the eventbased average interception loss was $14.5 \%-20.0 \%$ for the growing season and $6.9 \%-11.1 \%$ for the leafless season.

\section{Bark surface area $\left(B A_{\text {bark }}\right)$ and canopy storage $(S)$}

Figure 2 shows the relationship between $D_{\mathrm{BH}}$ and BA $\left(B_{\mathrm{BA}}\right.$ and $S_{\mathrm{BA}}$ ) for the Robinia plantation. Linear regression analysis for $B_{\mathrm{BA}}, S_{\mathrm{BA}}$ and $D_{\mathrm{BH}}$ showed that $\log \left(\mathrm{BA}_{\text {bark }}\right.$ ) was significantly positively correlated $(p<0.05)$ with $\log \left(D_{\mathrm{BH}}\right)$. However, there were marked differences in the slopes, intercepts and coefficients of determination between $B_{\mathrm{BA}}$ and $S_{\mathrm{BA}}$, indicating that they increased differently with increasing tree size. Overall, the estimated average BA_bark was $12.9 \mathrm{~m}^{2}$, with a range of $6.2-18.0 \mathrm{~m}^{2}$.

The estimated canopy storage for the Robinia plantation plots during the growing seasons and leafless seasons in 2015 and 2016 are shown in Figs. 4 and 5 and Figs. S1 and $\mathrm{S} 2$. The relationships between canopy interception loss and
Table 2 Throughfall, stemflow and interception loss in the plots during 2015-2016

\begin{tabular}{|c|c|c|c|c|c|c|}
\hline \multirow[t]{2}{*}{ Plot } & \multicolumn{3}{|c|}{ Growing season (May-October) } & \multicolumn{3}{|c|}{ Leafless season (November-April) } \\
\hline & $I$ & $T_{\mathrm{f}}$ & $S_{\mathrm{f}}$ & $I$ & $T_{\mathrm{f}}$ & $S_{\mathrm{f}}$ \\
\hline 1 & 196.4 & 786.1( & 19.5 & 25.5 & 208.6 & $6.0(2.5 \%)$ \\
\hline 2 & 187.4( & $789.2(7$ & 25.6 & 24.5 & 211.4 & $4.2(1.8 \%)$ \\
\hline 3 & $199.9(20.0 \%)$ & $777.1(77.6 \%)$ & $25.1(2.5 \%)$ & $26.7(11.1 \%)$ & $209.8(87.4 \%)$ & $3.6(1.5 \%)$ \\
\hline 4 & $194.4(19.4 \%)$ & $782.1(78.1 \%)$ & $25.6(2.6 \%)$ & $25.9(10.8 \%)$ & $209.0(87.1 \%)$ & $5.2(2.2 \%)$ \\
\hline 5 & $150.8(15.1 \%)$ & $843.3(84.2 \%)$ & $8.0(0.8 \%)$ & $17.5(7.3 \%)$ & $216.0(90.0 \%)$ & $6.6(2.8 \%)$ \\
\hline 6 & $145.3(14.5 \%)$ & $851.8(85.0 \%)$ & $5.0(0.5 \%)$ & $16.6(6.9 \%)$ & $218.7(91.1 \%)$ & $4.8(2.0 \%)$ \\
\hline 1 & $186.4(18.6 \%)$ & $801.7(80.0 \%)$ & $14.0(1.4 \%)$ & $21.8(9.1 \%)$ & $214.4(89.3 \%)$ & $3.8(1.6 \%)$ \\
\hline 8 & $174.9(17.5 \%)$ & $821.2(82.0 \%)$ & $6.0(0.6 \%)$ & $21.5(9.0 \%)$ & $215.1(89.6 \%)$ & $3.4(1.4 \%)$ \\
\hline 9 & $177.4(17.7 \%)$ & $815.7(81.4 \%)$ & $9.0(0.9 \%)$ & $22.2(9.3 \%)$ & $213.4(88.9 \%)$ & $4.4(1.9 \%)$ \\
\hline Mean & $179.2(17.9 \%) \mathrm{a}$ & $807.6(80.6 \%) b$ & $15.3(1.5 \%) b$ & $22.6(9.4 \%) \mathrm{a}$ & $213.0(88.7 \%) \mathrm{a}$ & $4.6(1.9 \%) a$ \\
\hline
\end{tabular}

$I$ is interception loss; $T_{\mathrm{f}}$ is throughfall and $S_{\mathrm{f}}$ is stemflow; gross rainfall during growing and leafless seasons are $1002.1 \mathrm{~mm}$ and $240.1 \mathrm{~mm}$, respectively, the number of rainfall events during growing and leafless seasons are 120 and 43, respectively; values in parentheses are the percentage to corresponding gross rainfall; different lower-case letters in the mean value $(\%)$ between the growing and leafless seasons indicate significant difference at $p<0.05$. Growing season: May 2015-Oct. 2015 and May 2016-Oct. 2016; Leafless season 2015: Jan.-Apr. and Nov.-Dec.; 2016: Jan.-Apr. and Nov.-Dec 

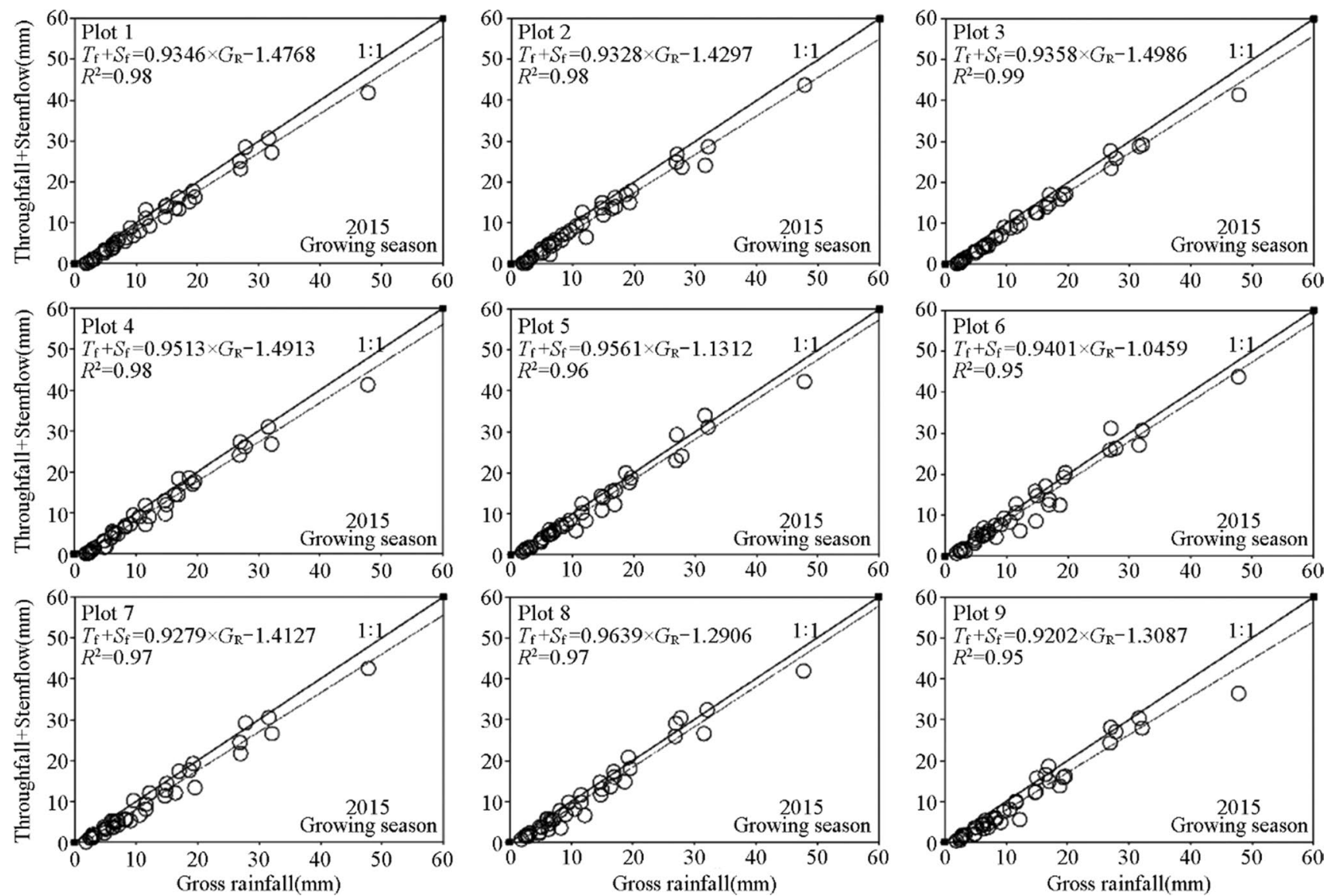

Fig. 4 Linear flux-response relationship (Spearman correlation) between POD1 within the Light Exposed Sampling Site (POD1_ LESS) and the percentage of symptomatic plant species within the

the sum of throughfall and stemflow differed between the plots and seasons. Over the study period, the estimated average canopy storage was $0.8 \pm 0.1 \mathrm{~mm}$, with the highest average $(0.9 \mathrm{~mm})$ occurring in plot 3 and the lowest $(0.6 \mathrm{~mm})$ in plot 6 . For the different seasons, the estimated average $S$ was $1.3 \pm 0.1 \mathrm{~mm}$ and range of $1.0-1.5 \mathrm{~mm}$ for the growing season. This dropped significantly $(p<0.05)$ to an average of $0.2 \mathrm{~mm}$ and range of $0.1-0.3 \mathrm{~mm}$ for the leafless season.

\section{Canopy structure variables and hydrological relationships}

The relationships between canopy structure variables, including tree density (trees ha $\left.{ }^{-1}\right)$, TH $(\mathrm{m}), \mathrm{BA}\left(\mathrm{m}^{2} \mathrm{ha}^{-1}\right)$, $C$ and BA bark $_{\text {(n) }}\left(\mathrm{m}^{2}\right.$ tree $\left.^{-1}\right)$, LAI/WAI $\left(\mathrm{m}^{2} \mathrm{~m}^{-2}\right)$ and canopy hydrological components of $S$ and $I: P_{\mathrm{g}}$ are plotted in Figs. 6 and 7. On the whole, linear relationships existed between the six canopy structure indices and the two canopy hydrological components. The performance was more robust (except for tree density) in the leafless season than in the growing season. $R^{2}$ values were different among the relationships,
LESS (VI_LESS) over the period 2017-2019 ( $n=24)$, with 95\% confidence interval of observed (gray line) and predicted (dot-dashed gray line) values

indicating that controls on canopy structure were different for $S$ and $I: P_{\mathrm{g}}$. Based on the $R^{2}$, the correlations generally indicated that $C$ and LAI/WAI were the key canopy structure variables driving the variations of $S$ and $I: P_{\mathrm{g}}$, followed by $\mathrm{BA}_{\text {bark }}, \mathrm{BA}, \mathrm{TH}$ and tree density (Figs. 6 and 7).

\section{Multiple linear regression analysis}

For the experimental periods of the growing season and leafless season in 2015, canopy structure variables ( $C$, LAI/ WAI and BA bark $)$ with significant correlations $(p<0.05$, $R^{2}>0.65$ ) with canopy hydrological components (i.e., $S$ and $I: P_{\mathrm{g}}$, were used to build the multiple regression models for the prediction of $S$ and $I: P_{\mathrm{g}}$ (Table 3). Three variables were positively linearly correlated with $S$ and $I: P_{\mathrm{g}}$, with $R^{2}>0.98$ for $S$ and $R^{2}>0.96$ for $I: P_{\mathrm{g}}$. This suggested that the variables were key indicators for canopy hydrological components. To test and verify the regression models, observed and simulated values of $S$ and $I: P_{\mathrm{g}}$ for the growing season and the leafless season in 2016 were compared (Fig. 8). The results showed that the slopes of the linear regressions between the 

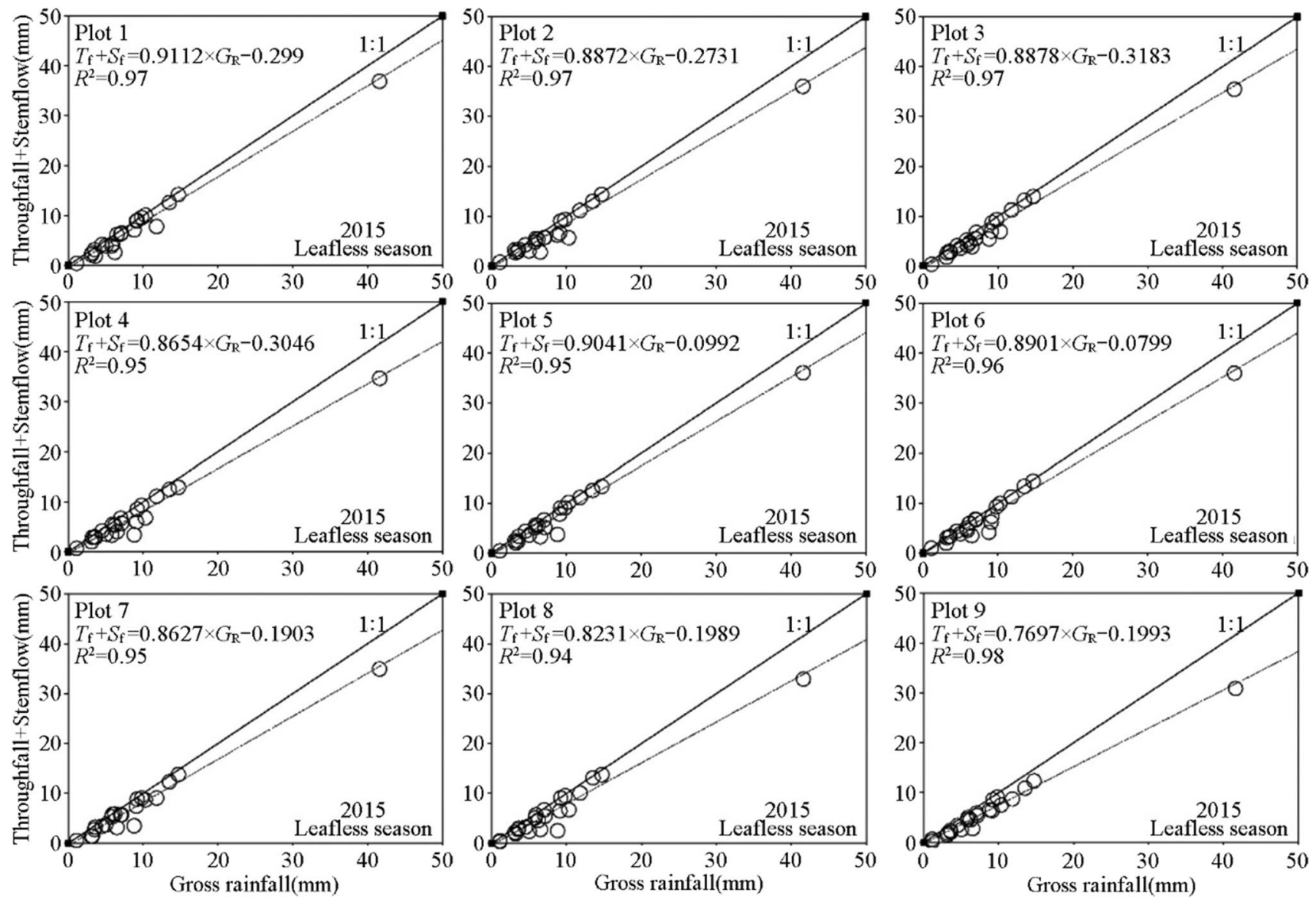

Fig. 5 Estimation of canopy storage capacity $(S, \mathrm{~mm})$ during the leafless season (November-April) in 2015 according to Wallace and McJannet (2008); $T_{\mathrm{f}}$ is throughfall, $S_{\mathrm{f}}$ stemflow and $G_{\mathrm{R}}$ gross rainfall

observed and simulated values were close to $1.0(0.90-1.14)$ with $R^{2}>0.95$. This indicated that the regression models had an overall robust and stable performance.

\section{Discussions}

\section{Canopy interception loss}

During the growing season, average canopy interception loss was $17.9 \%$ of $P_{\mathrm{g}}$, consistent with the $18.4 \%$ reported by Ma et al. (2019) and the $20.0 \%$ reported by Sadeghi et al. (2016) for a Robinia pseudoacacia plantation in a semiarid region in Iran. For the leafless season, average interception loss for all plots was $9.4 \%$, similar to the $9.2 \%$ report by Ma et al. (2019). The significantly higher $(p<0.05)$ interception loss percentage for growing season relative to the leafless season is in agreement with the findings in other studies for $R$. pseudoacacia plantations and for deciduous forests (Levia and Frost 2003; Šraj et al. 2008; Fathizadeh et al. 2018; Ma et al. 2019). The decrease in percent interception loss for the leafless season was likely due to the loss in leaf mass, LAI and $C$. This is evident in the positive relationship between LAI, $C$ and canopy interception loss percent plotted in Fig. 6 (Park and Cameron 2008; Molina and del Campo 2012). The drop in interception loss (or increase in net rainfall) in forest ecosystems increased soil water content, which in turn enhanced tree growth and water use efficiency (Worbes 1999). Thus, in water-limited arid/semiarid regions, where rainfall is the main source of water for vegetation growth, management policies should be driven by prevailing water conditions, e.g., thinning vegetation to limit canopy interception loss and the resilience/resistance of remaining trees to drought stress. 

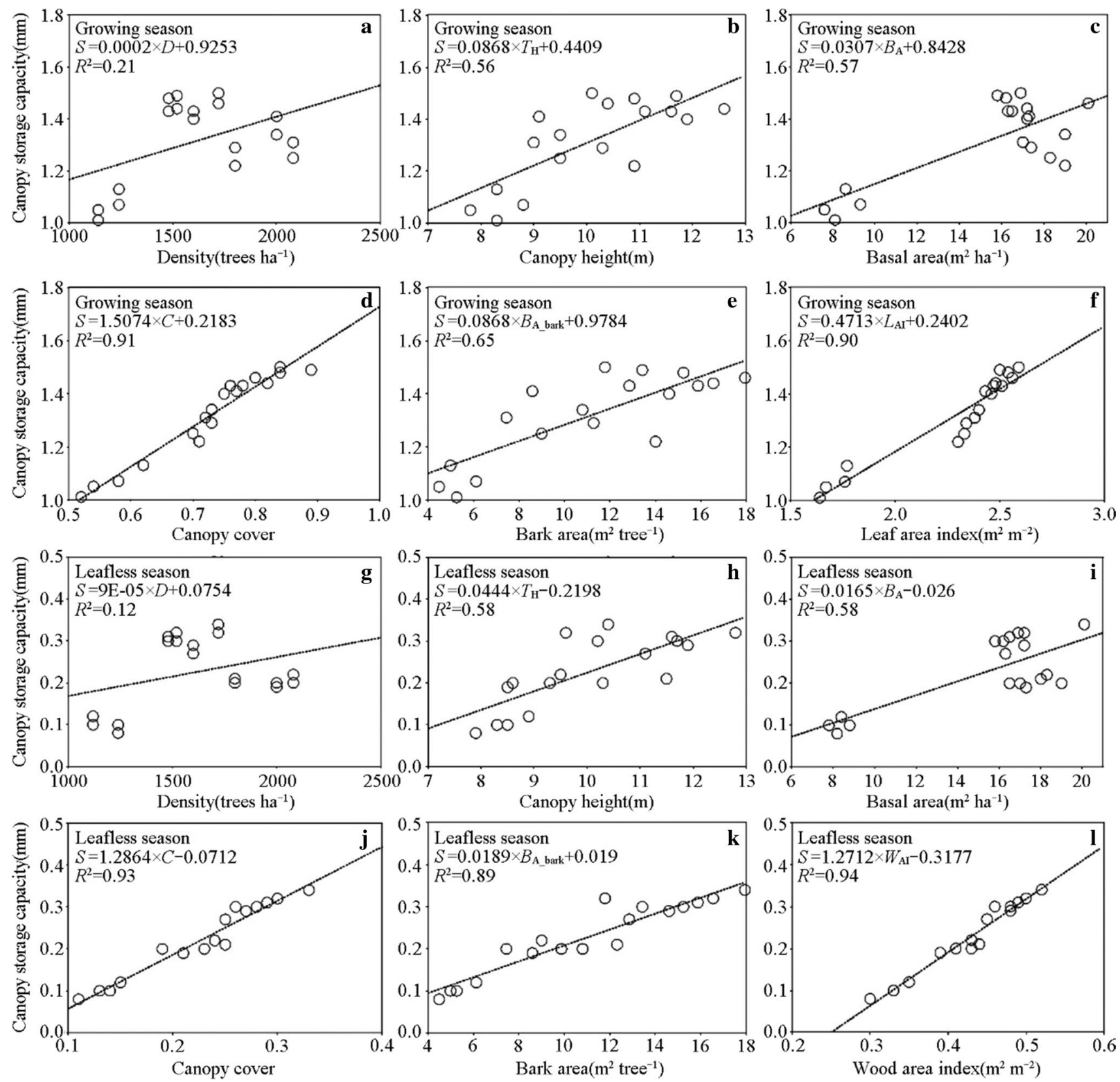

Fig. 6 The relationship between canopy storage capacity and canopy variables: tree density $\left(D\right.$, trees ha $\left.{ }^{-1}\right)$, canopy height $\left(T_{\mathrm{H}}, \mathrm{m}\right)$, basal area $\left(B_{\mathrm{A}}, \mathrm{m}^{2} \mathrm{ha}^{-1}\right)$, canopy cover $(C)$, bark area $\left(B_{\mathrm{A} \_ \text {bark }}, \mathrm{m}^{2}\right.$ tree $\left.{ }^{-1}\right)$

\section{Bark surface area $\left(\mathrm{BA}_{\text {bark }}\right)$ and canopy storage capacity (S)}

For all plots, $\log \left(S_{\mathrm{BA}}\right.$ or $\left.B_{\mathrm{BA}}\right)$ was significantly $(p<0.05)$ and positively correlated with $\log \left(D_{\mathrm{BH}}\right)$ (Levia and Herwitz 2005; Hofhansl et al. 2012). Similarly, Whittaker and Woodwell (1967) investigated BA_bark relations with $D_{\mathrm{BH}}$ in temperate deciduous forest communities and noted that and leaf/wood area index $\left(L_{\mathrm{AI}} / W_{\mathrm{AI}}, \mathrm{m}^{2} \mathrm{~m}^{-2}\right)$ for all plots during the growing seasons and leafless seasons in 2015 and 2016

$S_{\mathrm{BA}}$ or $B_{\mathrm{BA}}$ could be estimated from the regression of log $\left(\mathrm{BA}_{\text {bark }}\right)$ and $\log \left(D_{\mathrm{BH}}\right)$.

In terms of $S$, the average values were significantly higher $(p<0.05)$ for the growing season $(1.3 \mathrm{~mm})$ than for the leafless season $(0.2 \mathrm{~mm})$; this is consistent with the findings in other Robinia pseudoacacia plantations and deciduous forests (Carlyle-Moses and Price 2007; Fathizadeh et al. 2017; Ma et al. 2019). Carlyle-Moses and Gash (2011) noted that $S$ is influenced by several factors such as plant morphological attributes (e.g., LAI, $C$, BA_bark and 

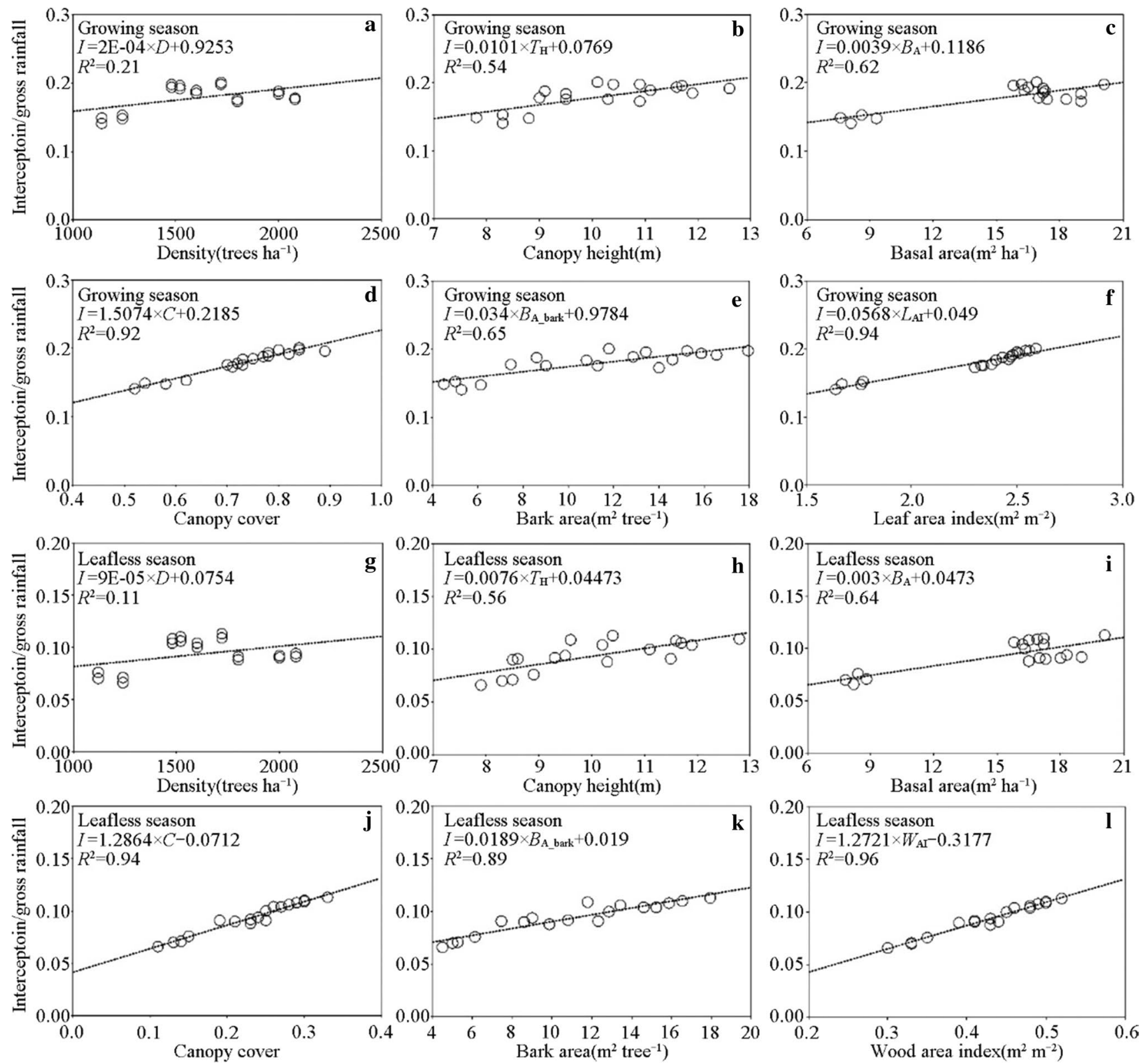

Fig. 7 Relationship between the relative interception loss (the ratio of interception to gross rainfall) and canopy variables: tree density $\left(D\right.$, trees ha $\left.{ }^{-1}\right)$, canopy height $\left(T_{\mathrm{H}}, \mathrm{m}\right)$, basal area $\left(B_{\mathrm{A}}, \mathrm{m}^{2} \mathrm{ha}^{-1}\right)$, can-

BA) and rainfall characteristics (rainfall intensity, duration and amount, and rain drop size distribution), climatic conditions (wind speed and direction) and measurement errors. This makes it difficult to generalize the behavior of $S$. However, this study showed that the decrease in canopy storage capacity during the leafless season depended mainly on the reduction in LAI and $C$. This is reflected in the positive relationship between $C$, LAI (WAI) and $S$ (Waterloo et al. 1999; Fathizadeh et al. 2017; Ma et al. 2019). opy cover $(C)$, bark area $\left(B_{\mathrm{A} \text { bark }}, \mathrm{m}^{2}\right.$ tree $\left.^{-1}\right)$ and leaf/wood area index $\left(L_{\mathrm{AI}} / W_{\mathrm{AI}}, \mathrm{m}^{2} \mathrm{~m}^{-2}\right)$ for all plots during the growing seasons and leafless seasons in 2015 and 2016

\section{Key canopy characteristics controlling $S$ and I: $P_{g}$}

Rutter et al. (1975) and Gash et al. (1995) noted that canopy interception loss is driven by $S, C$, wet-canopy evaporation rate, rainfall characteristics ( rainfall intensity and amount) and other plant morphological traits, for example, trunk water storage capacity and the proportion of rainwater diverted into stemflow. Among these factors, $S$ and $C$ are the two most important traits driving interception loss (Fathizadeh et al. 2017). Moreover, $S$ has a close relationship with canopy structure parameters such as LAI, $C$, TH, 
Table 3 Results of multiple regression models investigating canopy storage capacity $(S)$ and relative interception loss (interception/gross rainfall) to the predictor variables bark area $\left(\mathrm{m}^{2} /\right.$ tree $)$, canopy cover (C) and leaf /wood area index (LAI,WAI), $\mathrm{m}^{2} \mathrm{~m}^{-2}$ ) for all plots in 2015

\begin{tabular}{|c|c|c|c|c|}
\hline \multirow[t]{2}{*}{ Coefficients } & \multicolumn{2}{|c|}{$\begin{array}{l}\text { Growing season (May- } \\
\text { October) }\end{array}$} & \multicolumn{2}{|c|}{$\begin{array}{l}\text { Leafless season } \\
\text { (November-April) }\end{array}$} \\
\hline & $S$ & $\begin{array}{l}\text { Relative inter- } \\
\text { ception }\end{array}$ & $S$ & $\begin{array}{l}\text { Relative } \\
\text { intercep- } \\
\text { tion }\end{array}$ \\
\hline Intercept & 0.272 & 0.059 & -0.217 & 0.015 \\
\hline SE & 0.105 & 0.013 & 0.094 & 0.022 \\
\hline$p$-value & 0.041 & 0.004 & 0.061 & 0.509 \\
\hline Bark area & 0.002 & 0.001 & 0.007 & 0.001 \\
\hline SE & 0.006 & 0.001 & 0.003 & 0.001 \\
\hline$p$-value & 0.108 & 0.065 & 0.037 & 0.041 \\
\hline$c$ & 0.842 & 0.067 & 0.107 & 0.053 \\
\hline SE & 0.306 & 0.039 & 0.026 & 0.121 \\
\hline$p$-value & 0.033 & 0.013 & 0.015 & 0.067 \\
\hline LAI (WAI) & 0.181 & 0.029 & 0.824 & 0.140 \\
\hline SE & 0.081 & 0.010 & 0.477 & 0.110 \\
\hline$p$-value & 0.046 & 0.021 & 0.013 & 0.024 \\
\hline $\mathrm{R}^{2}$ & 0.98 & 0.97 & 0.99 & 0.96 \\
\hline$F$-statistic & 91.17 & 77.35 & 100.19 & 57.15 \\
\hline$p$-value & 0.00 & 0.00 & 0.00 & 0.00 \\
\hline
\end{tabular}

BA_bark,$D_{\mathrm{BH}}$ and tree density (Deguichi et al. 2006; Li et al. 2016). To explore the key factors of canopy structure controlling variations in $I$ and $S$ in $R$. pseudoacacia plots in this study, the relationships between average interception loss $\left(I: P_{\mathrm{g}}\right)$, canopy storage capacity $(S)$ and the six main canopy parameters (stand density, TH, BA_bark, $C, \mathrm{BA}$ and LAI/WAI) during the growing seasons and the leafless seasons in 2015 and 2016 were depicted in scatter-plots (Figs. 6 and 7$)$. They show significant $(p<0.05)$ linear correlations between $S$ and $C$, LAI and BA bark for the growing season, explaining $91 \%, 90 \%$, and $65 \%$, respectively, of the variation in canopy storage capacity (Figs. 8d-f). The correlations $\left(R^{2}=0.65-0.91\right)$ of $S$ to $C$, LAI and BA_bark were stronger than those of $S$ to BA and HT $\left(R^{2}=0.56-0.57\right)$. Fathizadeh et al. (2017) carried out a study in Zagros forest in a semiarid region in Iran and noted that the correlations of $S$ to $C$, LAI and HT $\left(R^{2}=0.82-0.92\right)$ were similar to that of $S$ to BA $\left(R^{2}=0.93\right)$. However, there was no significant correlation between $S$ and stand density $\left(p=0.17 ; R^{2}=0.21\right)$ for the growing season (Fig. 6a), consistent with the report by Fathizadeh et al. (2017). Similar to the regression results for the growing season, correlations of $S$ to $C$, WAI and BSA $\left(R^{2}=0.89-0.94\right.$, Fig. 6) for the leafless season were stronger than that of $S$ to BA and TH $\left(R^{2}=0.58\right.$, Fig. 6$)$. There was also no significant correlation of $S$ to stand density $\left(p>0.05, R^{2}=0.12\right)$. Similarly, Fathizadeh et al. (2017) reported higher correlations $\left(R^{2}=0.70-0.97\right)$ of $S$ to canopy parameters including $C$, WAI and BA for the leafless season.

There was a significant relationship $(p<0.05)$ between I: $P_{\mathrm{g}}$ and $C$ and LAI for the growing season, accounting for $92 \%$ and $94 \%$, respectively, of the variation in $I: P_{\mathrm{g}}$ (Figs. $7 \mathrm{~d}$, and 7f). The positive correlations of $C$ and LAI to $I: P_{\mathrm{g}}$ were significantly higher $(p<0.05)$ than those of BA_bark and BA to $I$ : $P_{\mathrm{g}}$ (Fathizadeh et al. (2017). However, in a study of a lower montane rainforest in Central Sulawesi in
Fig. 8 Comparison between observed and predicted relative interception loss $(I: P g)$ and canopy storage capacity $(S)$ during the growing season and leafless season in 2016
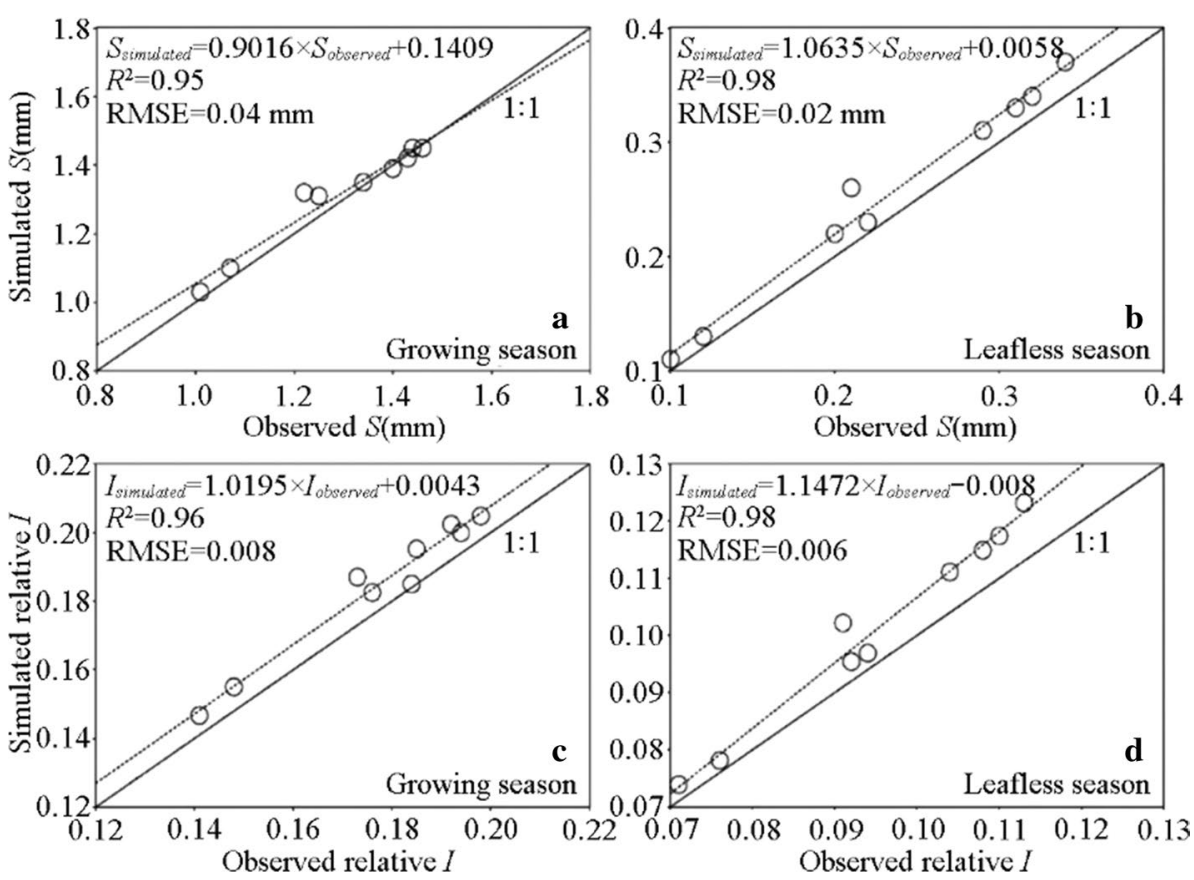
Indonesia, Dietz et al. (2006) found that LAI and $C$ were weakly negatively correlated with interception loss, but had a higher positive correlation of $\mathrm{BA}_{\text {bark }}$ with interception loss. In studies of two boreal forests in Siberia and five temperate forests in Japan, Toba and Ohta (2005) observed that canopy interception loss was inversely correlated with LAI/ WAI. This was attributed to the stronger effect of meteorological variables on interception loss than in canopy structure. Dietz et al. (2006) also noted that canopy interception loss was significantly positively correlated $(p<0.01)$ with TH. Although this was similar to the findings in this study, the correlations in our study were much weaker (with much lower $R^{2}$ ) than those reported by Dietz et al. (2006) and Fathizadeh et al. (2017). In this study, stand density was not significantly correlated with canopy interception loss (Dietz et al. 2006; Fathizadeh et al. 2017). In the leafless season, the correlation of $I: P_{\mathrm{g}}$ with each of the six canopy parameters was similar to the regression results obtained for the growing season with similar $R^{2}$. WAI and $C$ were highly correlated with interception loss, followed by BA_bark, BA, $\mathrm{TH}$ and tree density.

The findings in this study, to some extent, indicate that the methods used in some canopy interception loss models driven by canopy parameters (such as $S$ and $C$ ), should consider LAI/WAI and tree BA_bark for deciduous species under environmental/hydroclimatic conditions similar to those on the Loess Plateau. However, a more in-depth analysis of the correlation between canopy interception loss and LAI/WAI and tree $\mathrm{BA}_{\text {bark }}$ is still needed. This can be guided on the basis of individual rainfall events to better show the effects of LAI/WAI and tree BA_bark on canopy interception loss.

\section{Multiple regression equations for $S$ and $I: P_{g}$}

To accurately predict canopy interception loss, multiple regression models, instead of the frequently used single regression models, for the influencing factors of rainfall interception were used (Zheng et al. 2018). Rainfall characteristics (all amount, duration and intensity) have been used in combination with canopy structure parameters (e.g., leaf area index or LAI) to estimate interception loss (Zhang et al. 2015; Zheng et al. 2018). To better represent the effect of canopy parameters on $I: P_{\mathrm{g}}$ and $S$, three canopy parameters $\left(C, \mathrm{LAI} / \mathrm{WAI}\right.$ and tree $\left.\mathrm{BA}_{\text {bark }}\right)$, strongly correlated with relative interception loss and $S$, were used to establish the regression equations for the estimation of $I: P_{\mathrm{g}}$ and $S$ (Table 3). The results indicate that regression equations with the selected canopy parameters greatly improved estimation of $I: P_{\mathrm{g}}$ and $S$. The correlations of $I: P_{\mathrm{g}}$ and $S$ in combination with $C$, $\mathrm{LAI} / \mathrm{WAI}$ and $\mathrm{BA}_{\text {bark }}$ were all more significant $(p<0.05)$ than with individual $C$, LAI/WAI and BA_bark for both growing seasons and leafless seasons. The combined parameters explained $97 \%$ and $96 \%$ of the variations in $I: P_{\mathrm{g}}$ for the growing seasons and leafless seasons, respectively. The corresponding values of $S$ for the growing seasons and leafless seasons were $98 \%$ and $99 \%$, respectively.

To test and verify the application of the regression models developed in this study, the predicted relative interception loss and $S$ from regression models were further compared with measured values for the growing season and leafless season in 2016 (Fig. 8). It showed that the slopes of the linear regressions between the simulated and observed values $\left(I: P_{\mathrm{g}}\right.$ and $\left.S\right)$ were close to 1.0, suggesting satisfactory performance of the models. However, the RMSE for the observed and simulated $I: P_{\mathrm{g}}$ and $S$ was slightly higher for the growing season $\left(I: P_{\mathrm{g}}=0.008 ; S=0.04 \mathrm{~mm}\right)$ than for the leafless season $\left(I: P_{\mathrm{g}}=0.006 ; S=0.02 \mathrm{~mm}\right)$. This indicated less influence of the three canopy parameters, $C$, LAI and BSA on $I: P_{\mathrm{g}}$ and $S$ during the growing season. The relatively higher RMSE and lower $R^{2}$ of the simulated and measured $I: P_{\mathrm{g}}$ and $S$ for the growing season in 2016 was caused by the larger differences in $C$ and LAI between 2015 and 2016. In this study, the regression models used were based on measured data in 2015, for which mean values of $C=0.75$ and $\mathrm{LAI}=2.33 \mathrm{~m}^{2} \mathrm{~m}^{-2}$ were higher than those in 2016, with means of $C=0.71$ and $\mathrm{LAI}=2.21 \mathrm{~m}^{2} \mathrm{~m}^{-2}$. This potentially induced larger bias in the coefficients of the regression models (Table 3 ) that eventually resulted in even larger bias in the simulated and observed $I: P_{\mathrm{g}}$ and $S$ in 2016 (Fig. 8).

\section{Implications of the regression models}

The results confirmed that canopy hydrological components such as $I$ and $S$ have a strong correlation with canopy structure variables such as leaf area index, canopy cover, height, bark area, diameter at breast height and stand density. Thus, to investigate the effects of changes in canopy structure on the water balance in forest watersheds, the correlation between canopy structure variables and canopy hydrological processes cannot be ignored. Moreover, changes in canopy structure variables such as canopy cover and leaf area index induced by tree dieback or mortality can directly limit transpiration and interception loss of rainwater, influencing variations in soil water and surface runoff. Thus, species with large- scale dieback and mortality, as was the case in most $R$. pseudoacacia plantations on the Loess Plateau, can have substantial indirect effects on hydrological processes and regional water balances. The strong correlation between dieback and mortality and canopy variables observed in this study can help to better understand their effects on plant hydrological processes. 


\section{Conclusions}

In this study, approximately $18 \%$ in the growing season and $9 \%$ in the leafless season of gross rainfall in semiarid Robinia pseudoacacia plantations evaporated back into the atmosphere during or after a rainfall event. Average canopy storage capacity estimated using the regression method of Wallace and McJannet (2008) was $1.3 \mathrm{~mm}$ for the growing season and $0.2 \mathrm{~mm}$ for the leafless season. Canopy structure variables, including leaf/wood area index (LAI/WAI), canopy cover, height, bark area, diameter, and stand density were good indictors of canopy hydrological processes such as relative interception loss and storage capacity, although this changed with changing variables and seasons. With canopy cover, leaf/wood area index, and bark area, canopy hydrological components for both the growing seasons and the leafless seasons were predicted accurately by the regression models developed in this study. Overall, canopy structure variables were informative in predicting canopy hydrological processes. However, further studies with further description of the linkages between canopy structure variables, including the ones used in this study, and canopy hydrological processes are needed for better understanding of the effects of changes in canopy morphology on forest hydrological processes for integration into future hydrological models.

Acknowledgements We acknowledge the inputs of Dr. X. Li, Dr. Q. Zhang and Dr. C. Zhang in terms of data collection and insignificant suggestions during the study.

Authors contribution Changkun Ma and Yi Luo did the conceptual framework and design; acquisition, analysis and interpretation of data; and drafting of the articale. Mingan Shao also participated in the conceptualization and design of the paper. Jia xiaoxu and Changkun Ma participated in the acquisition of the data. Then all the authors proofread the manuscript and approved the final manuscript.

Open Access This article is licensed under a Creative Commons Attribution 4.0 International License, which permits use, sharing, adaptation, distribution and reproduction in any medium or format, as long as you give appropriate credit to the original author(s) and the source, provide a link to the Creative Commons licence, and indicate if changes were made. The images or other third party material in this article are included in the article's Creative Commons licence, unless indicated otherwise in a credit line to the material. If material is not included in the article's Creative Commons licence and your intended use is not permitted by statutory regulation or exceeds the permitted use, you will need to obtain permission directly from the copyright holder. To view a copy of this licence, visit http://creativecommons.org/licenses/by/4.0/.

\section{References}

Allen CD, Breshears DD (1998) Drought-induced shift of a forestwoodland ecotone: rapid landscape response to climate variation. Proc Natl Acad Sci USA 95(25):14839-14842
Anderegg WRL, Kane JM, Anderegg LDL (2013) Consequences of widespread tree mortality triggered by drought and temperature stress. Nat Clim Change 3(1):30-36

Baret F, Weiss M (2004) Can-eye: processing digital photographs for canopy structure characterization. Paris: (147, rue de l'Université - 75338 Paris CEDEX 07) INRA Press, p 1-56

Carlyle-Moses DE, Gash JHC (2011) Rainfall interception loss by forest canopies. Forest hydrology and biogeochemistry: synthesis of past research and future directions. Springer, Switzerland, pp 407-423

Carlyle-Moses DE, Price AG (2007) Modelling canopy interception loss from a Madrean pine-oak stand, northeastern Mexico. Hydrol Process 21(19):2572-2580

Chang M (2003) Forest hydrology: an introduction to water and forests. Taylor \& Francis, CRC Press, Milton Park, pp 10-595

Crockford RH, Richardson DP (2000) Partitioning of rainfall into throughfall, stemflow and interception: effect of forest type, ground cover and climate. Hydrol Process 14(16-17):2903-2920

Deguichi A, Hattori S, Park HT (2006) The influence of seasonal changes in canopy structure on interception loss: application of the revised Gash model. J Hydrol 318(1-4):80-102

Dietz J, Hölscher D, Leuschner C, Hendrayanto (2006) Rainfall partitioning in relation to forest structure in differently managed montane forest stands in Central Sulawesi. Indonesia Forest Ecol Manag 237(1-3):170-178

Domingo F, Sanchez G, Moro MJ, Brenner AJ, Puigdefabregas J (1998) Measurement and modelling of rainfall interception by three semiarid canopies. Agric Forest Meteorol 91(3-4):275-292

Du S, Wang YL, Kume T, Zhang JG, Otsuki K, Yamanaka N, Liu GB (2011) Sapflow characteristics and climatic responses in three forest species in the semiarid Loess Plateau region of China. Agric Forest Meteorol 151(1):1-10

Fan JL, Oestergaard KT, Guyot A, Lockington DA (2014) Measuring and modeling rainfall interception losses by a native Banksia woodland and an exotic pine plantation in subtropical coastal Australia. J Hydrol 515:156-165

FAO (2015) Global guidelines for the restoration of degraded forests and landscapes in drylands: building resilience and benefiting livelihoods. FAO Forestry Paper 175. Food and Agriculture Organization of the United Nations, Rome, Italy. http://www.fao. org/3/a-i5036e.pdf.

Fathizadeh OS, Hosseini M, Zimmermann A, Keim RF, Boloorani AD (2017) Estimating linkages between forest structural variables and rainfall interception parameters in semi-arid deciduous oak forest stands. Sci Total Environ 601-602:1824-1837

Fathizadeh OS, Hosseini M, Keim RF, Boloorani AD (2018) A seasonal evaluation of the reformulated Gash interception model for semi-arid deciduous oak forest stands. Forest Ecol Manag 409:601-613

Feng XM, Fu BJ, Piao SL, Wang S, Ciais P, Zeng ZZ, LüYH ZY, Li Y, Jiang XH, Wu BF (2016) Revegetation in China's Loess Plateau is approaching sustainable water resource limits. Nat Clim Change 6(11):1019-1022

Franklin JF, Shugart HH, Harmon ME (1987) Tree death as an ecological process. Bioscience 37:550-556

Galdos V, Alvarez FC, Garcia A, Revilla JA (2012) Estimated distributed rainfall interception using a simple conceptual model and moderate resolution imaging spectroradiometer (MODIS). J Hydrol 468:213-228

Gash JHC, Lloyd CR, Lachaud G (1995) Estimating sparse forest rainfall interception with an analytical model. J Hydrol 170(1-4):79-86

Gerrits AMJ (2010) The role of interception in the hydrological cycle. Water Resources Section. Faculty of Civil Engineering and Geoscience. Netherlands, Delft University of Technology Press, p. 10-45 
Guarin A, Taylor AH (2005) Drought triggered tree mortality in mixed conifer forests in Yosemite National Park, California, USA. Forest Ecol Manag 218(1-3):229-244

Hofhansl F, Wanek W, Drage S, Huber W, Weissenhofer A, Richter A (2012) Controls of hydrochemical fluxes via stemflow in tropical lowland rainforests: effects of meteorology and vegetation characteristics. J Hydrol 452-453:247-258

Hormann G, Branding A, Clemen T, Herbst M, Hinrichs A, Thamm F (1996) Calculation and simulation of wind controlled canopy interception of a beech forest in northern Germany. Agric Forest Meteorol 79(3):131-148

Jia XX, Shao MA, Zhu YJ, Luo Y (2017) Soil moisture decline due to afforestation across the Loess Plateau, China. J Hydrol 546:113-122

Klaassen W, Bosveld F, Water ED (1998) Water storage and evaporation as constituents of rainfall interception. J Hydrol 212(1-4):36-50

Levia DF, Frost EE (2003) A review and evaluation of stemflow literature in the hydrologic and biogeochemical cycles of forested and agricultural ecosystems. J Hydrol 274(1-4):1-29

Levia DF, Herwitz SR (2005) Interspecific variation of bark water storage capacity of three deciduous tree species in relation to stemflow yield and solute flux to forest soils. CATENA 64(1):117-137

Li X, Xiao QF, Niu JZ, Dymond S, van Doorn NS, Yu XX, Xie BY, Lv XZ, Zhang KB, Li J (2016) Process-based rainfall interception by small trees in Northern China: the effect of rainfall traits and crown structure characteristics. Agric Forest Meteorol 218:65-73

Llorens P, Domingo F (2007) Rainfall partitioning by vegetation under Mediterranean conditions. A review of studies in Europe. J Hydrol 335(1-2):37-54

Llorens P, Gallart F (2000) A simplified method for forest water storage capacity measurement. J Hydrol 240(1-2):131-144

Ma CK, Luo Y, Shao MA, Li XX, Sun L, Jia XX (2017) Environmental controls on sap flow in black locust forest in Loess Plateau, China. Sci Rep 7(1): 13160

Ma CK, Li XX, Luo Y, Shao MA, Sun L, Jia XX (2019) The modelling of rainfall interception in growing and dormant seasons for a pine plantation and a black locust plantation in semi-arid Northwest China. J Hydrol 577:123849

Macfarlane C, Hoffman M, Eamus D, Kerp N, Higginson S, McMurtrie R, Adams M (2007) Estimation of leaf area index in eucalypt forest using digital photography. Agric Forest Meteorol 143(3-4):176-188

Molina AJ, del Campo AD (2012) The effects of experimental thinning on throughfall and stemflow: a contribution towards hydrology-oriented silviculture in Aleppo pine plantations. Forest Ecol Manag 269:206-213

Park A, Cameron JL (2008) The influence of canopy traits on throughfall and stemflow in five tropical trees growing in a Panamanian plantation. Forest Ecol Manag 255(5-6):1915-1925

Price AG, Carlyle-Moses DE (2003) Measurement and modelling of growing-season canopy water fluxes in a mature mixed deciduous forest stand, southern Ontario, Canada. Agric Forest Meteorol 119(1-2):69-85

Pypker TG, Bond BJ, Link TE, Marks D, Unsworth MH (2005) The importance of canopy structure in controlling the interception loss of rainfall: Examples from a young and an old-growth Douglas-fir forest. Agric Forest Meteorol 130(1-2):113-129
Rutter AJ, Morton AJ, Robins PC (1975) A predictive model of rainfall interception in forests. II. Generalization of the model and comparison with observations in some coniferous and hardwood stands. J Appl Ecol 12(1):367-380

Sadeghi SMM, Attarod P, Van Stan JT, Pypker TG, Dunkerley D (2015) Efficiency of the reformulated Gash's interception model in semiarid afforestations. Agric Forest Meteorol 201:76-85

Sadeghi SM, Attarod MP, Van Stan JT, Pypker TG (2016) The importance of considering rainfall partitioning in afforestation initiatives in semiarid climates: a comparison of common planted tree species in Tehran, Iran. Sci Total Environ 568:845-855

Savage M (1994) Anthropogenic and natural disturbance and patterns of mortality in a mixed conifer forest in California. Can J Forest Res 24(6):1149-1159. https://doi.org/10.1139/x94-152

Sexton JO, Song XP, Feng M, Noojipady P, Anand A, Huang CQ, Kim DH, Kathrine MC, Channan S, DiMiceli C, John RT (2013) Global, 30-m resolution continuous fields of tree cover: Landsatbased rescaling of MODIS vegetation continuous fields with lidarbased estimates of error. Int J Digit Earth 6(5):427-448

Šraj M, Mitja B, Matjaž M (2008) Rainfall interception by two deciduous Mediterranean forests of contrasting stature in Slovenia. Agric Forest Meteorol 148(1):121-134

Tie Q, Hu HC, Tian FQ, Guan HD, Lin H (2017) Environmental and physiological controls on sap flow in a subhumid mountainous catchment in North China. Agric Forest Meteorol 240-241:46-57

Toba T, Ohta T (2005) An observational study of the factors that influence interception loss in boreal and temperate forests. J Hydrol 313(3-4):208-220

Wallace J, McJannet D (2008) Modelling interception in coastal and montane rainforests in northern Queensland, Australia. J Hydrol 348(3-4):480-495

Wang YH, Yu PT, Xiong W, Shen ZX, Guo MC, Shi ZJ, Du AP, Wang LM (2008) Water-yield reduction after afforestation and related processes in the semiarid liupan mountains, Northwest China. JAWRA J Am Water Resour Assoc 44(5):1086-1097

Waterloo MJ, Bruijnzeel LA, Vugts HF, Rawaqa TT (1999) Evaporation from Pinus caribaea plantations on former grassland soils under maritime tropical conditions. Water Resour Res 35(7):2133-2144

Whittaker RH, Woodwell GM (1967) Surface area relations of woody plants and forest communities. Am J Bot 54(8):931-939

Worbes M (1999) Annual growth rings, rainfall-dependent growth and long-term growth patterns of tropical trees from the Caparo Forest Reserve in Venezuela. J Ecol 87(3):391-403

Zhang YF, Wang XP, Hu R, Pan YX, Paradeloc M (2015) Rainfall partitioning into throughfall, stemflow and interception loss by two xerophytic shrubs within a rain-fed re-vegetated desert ecosystem, northwestern China. J Hydrol 527:1084-1095

Zheng J, Fan JL, Zhang FC, Yan SC, Xiang YZ (2018) Rainfall partitioning into throughfall, stemflow and interception loss by maize canopy on the semi-arid Loess Plateau of China. Agric Water Manag 195:25-36

Publisher's Note Springer Nature remains neutral with regard to jurisdictional claims in published maps and institutional affiliations. 